\title{
Meeting the Local Rice Needs in Nigeria Through Effective Weed Management
}

\author{
U. Ismaila ${ }^{1}$, A. C. Wada $^{1}$, E. Daniya ${ }^{2} \&$ A. U. Gbanguba ${ }^{1}$ \\ ${ }^{1}$ National Cereals Research Institute Badeggi, Bida, Niger State, Nigeria \\ ${ }^{2}$ Department of Crop Production, Federal University of Technology, Minna, Niger State, Nigeria \\ Correspondence: U. Ismaila, National Cereals Research Institute Badeggi, Bida, Niger State, Nigeria. E-mail: \\ ismailaumar72@yahoo.com
}

Received: June 13, 2012 Accepted: September 18, 2012 Online Published: December 10, 2012

doi:10.5539/sar.v2n2p37

URL: http://dx.doi.org/10.5539/sar.v2n2p37

\begin{abstract}
Nigeria is blessed with natural and human resources required to produce rice to meet its local consumption. These resources are spread across all the agro-ecological zones of the country. Despite the availability of these resources, rice production in Nigeria could still not meet the local consumption and over $40 \%$ of the crop is imported annually to complement the local production. Several studies have revealed biotic and abiotic stresses as the major impediment to the production of the crop. Weeds are the most prominent of all the stresses across all the ecologies in term of yield reduction, labour demand and control cost. Yield losses of 35-75\% and $70-100 \%$ have been recorded in low land and upland ecologies respectively as a result of weed interference. The problem of weed is worse than any of the other stress mentioned above except for water stress in low land ecology. This paper reviews the various weed management options that could be adopted for optimal rice yield, by the resource poor farmers of Nigeria.
\end{abstract}

Keywords: national rice needs, weeds interference, biotic and abiotic stresses, weed management, optimal rice yield

\section{Introduction}

Rice is a major food crop where global supply is not keeping pace with demand. Rice will remain the world's leading food crop with over half the world's population dependent on it for nutrition and calories. Rice production under current inputs and technologies will not meet projected population growth needs and meeting present and future demand will require increased use of inputs and technologies to improve yields (Rice today, 2010).

Nigeria has the potential and ecologies that are suitable for different rice varieties which can be harnessed to boost rice production to meet domestic demand, and to produce a surplus for export. It has a potential area for rice production of between 4.6 to 4.9 million hectares, however only 1.7 million hectares, representing $35 \%$, of total land mass is cropped to rice (Imolehin \& Wada, 2000).

Rice has a great potential and can play a critical role in contributing to food nutritional security, income generation, poverty alleviation and socio- economic growth of Africa (Defoer et al., 2006). Apart from food supply and food security being key issues in the Nigerian government's economic agenda, rice is perceived as playing a significant role in the country's food security objectives, as both the poor and the wealthy consume the commodity. The urban poor in particular spend one third of their disposable income on rice which make many farmers to diversify from cocoa and other tree crops to rice production because of the income they derive from the latter (Akande \& Akpokoje, 2003). It is an important food crop in many states of Nigeria and is increasingly preferred over many root and tuber crops.

Increased production of rice has been reported to be hampered predominantly by weeds. Weed is a plant growing where man does not want it to be. Almost any kind of plant can therefore be a weed, as long as it exists in a location or situation where it is considered undesirable. It also follows that a particular plant may be a weed in one situation and not a weed in another. For instance, a volunteer maize plant in rice field can rightly be called a weed even though maize is a crop plant. Many weed species have been reported to infest rice fields in Nigeria (Table 1). 
Table 1. Common weed species of rice and their preferred ecologies in Nigeria

\begin{tabular}{|c|c|c|c|}
\hline Weed species & Family & Common name & Ecology \\
\hline \multicolumn{4}{|l|}{ Broadleaves } \\
\hline Euphorbia spp. & Euphorbiaceae & Milkweed & Upland \\
\hline Commelina spp & Commelinaceae & Spreading day flower & Upland \\
\hline Ipomoea spp & Convolvulaceae & Wild potato & Upland/lowland \\
\hline Ludwigia spp. & Convolvulaceae & Waterprimrose & Lowland \\
\hline Striga sp. & Scrophulariaceae & Witch weed & Upland \\
\hline Boerhavia diffusa $(\mathrm{L})$ & Nyctaginaceae & Hog weed & Upland \\
\hline Bidens pilosa (Linn) & Asteraceae & Cobblers begs & Upland \\
\hline Amaranthus spinosus (Linn) & Amaranthaceae & Spiny amaranth & Upland \\
\hline Senna mimosoides (Linn) & Caesalpiniaceae & Japanese tea & Upland \\
\hline Ageratum conyzoides (Linn) & Asteraceae & Goat weed & Upland \\
\hline Cleome viscosa $(\mathrm{L})$ & Cleomaceae & Spider plant & Upland \\
\hline Phyllanthus amarus (Schum) & Euphorbiaceae & Shatterstone & Upland \\
\hline Sphenoclea zeylanica (Gaertn) & Campanulaceae & Chickenspike & Lowland \\
\hline Tridax procumbens (Linn) & Asteraceae & Tridax & Upland \\
\hline Nymphaea lotus (Linn) & Nymphaeaceae & Water lily & Deep water \\
\hline Aspilla africana (Pers.) & Asteraceae & Haemorrhage plant & Upland \\
\hline Oldenlandia corymbosa (Linn) & Rubiaceae & Morning glory weed & Upland \\
\hline Trianthema portulacastrum (Linn) & Aizoaceae & Giant pigweed & Upland \\
\hline \multicolumn{4}{|l|}{ Grasses } \\
\hline Brachiaria spp. & Poaceae & Signal grass & Upland \\
\hline Cynodon dactylon (Linn) & Poaceae & Bahamagrass & Upland \\
\hline Digitaria spp. & Poaceae & Digitgrass or crabgrass & Upland \\
\hline Eragrostis spp. & Poaceae & Lovegrass & Upland \\
\hline Paspalum sp. & Poaceae & Ditch millet & Upland \\
\hline Setaria $\mathrm{spp}$ & Poaceae & Foxtail grass & Upland \\
\hline Echinochloa spp & Poaceae & Junglerice & Lowland/hydromorphic \\
\hline Oryza barthii (A. Chev) & Poaceae & Barth'srice & Lowland \\
\hline Panicum spp. & Poaceae & Guineagrass & Upland \\
\hline Eleusine indica (Gaertin.) & Poaceae & Goosegrass & Upland \\
\hline Axonopus compressus (Sw.) & Poaceae & Broadleaf carpetgrass & Upland \\
\hline Imperata cylindrica (Anderss.) & Poaceae & Spear grass & Upland \\
\hline Pennisetum spp & Poaceae & Elephant grass & Upland \\
\hline Rottboellia cochinchinensis (Lour) & Poaceae & Itchgrass & Upland \\
\hline \multicolumn{4}{|l|}{ Sedges } \\
\hline Cyperus esculentus (Linn) & Cyperaceae & Yellow nutsedge & Upland \\
\hline Cyperus rotundus (Linn) & Cyperaceae & Purple nutsedge & Upland/lowland \\
\hline Kyllinga spp & Cyperaceae & Kyllinga & Upland/lowland \\
\hline Cyprus difformis (Linn) & Cyperaceae & $\begin{array}{l}\text { Small flowered umbrella } \\
\text { sedge }\end{array}$ & Lowland \\
\hline Cyprus haspan (Linn) & Cyperaceae & Sharp edge sedge & Lowland \\
\hline Cyprus iria (Linn) & Cyperaceae & Rice flat sedge & Upland/lowland \\
\hline Fimbristylis littoralis (Gaudet) & Cyperaceae & Fimbry & Upland/lowland \\
\hline Mariscus longibracteatus (Cherm.) & Cyperaceae & - & Lowland \\
\hline
\end{tabular}

Pandey (2009) reported that weeds are at present the major biotic constraint to increased rice production worldwide. Ukwungwu and Abo (2004) reported that weeds are the greatest bottleneck to increased yields and quality of rice in Nigeria. Previous studies have shown that weed occurrence is a constant component of the ecosystem in comparison to the epidemic nature of other which pests makes farmers unaware of the significant losses they incur from their infestation (Johnson et al., 1999). Johnson also observed that major impediment in 
the cultivation of rice is heavy weeds infestation particularly in upland ecology, which compete with the crop to such extent that it could get smothered. Thus, farmers spend over US $\$ 400 \mathrm{ha}^{-1}$, or $20 \%$ of their production costs to control weeds during the growing cycle (Islam et al., 2005). Improving weed control in farmers' fields was shown to increase rice yields by $15-23 \%$, depending on the agro-ecosystem, and it is estimated that weeds may account for annual rice yield losses in sub Sahara Africa of at least 2.2 million tonnes equating to US \$1.45 billion (Rodenburg \& Johnson, 2009). The authors noted that rice yield losses due to uncontrolled weed growth was $28-74 \%$ in transplanted lowland rice, $28-89 \%$ in direct-seeded lowland rice and $48-100 \%$ in upland ecosystems.

Rice researchers in Nigeria have documented a great amount of useful scientific informations on weed management in all the rice ecologies of the country. These are however, scattered among many journals and books, which are not always accessible by Nigerian rice farmers. This paper summarizes important information on weed management practices in rice with the aim of providing essential, practical, up-to-date information for use by rice extension workers, farmers, teachers, and students in order to boost rice production and reduce the importation that at present is above $40 \%$ (Figure 1). It is imperative that an effective weed management mechanism and its effective adoption will result in better productivity and increase in net rice production which will in turn ensure food security in Nigeria.

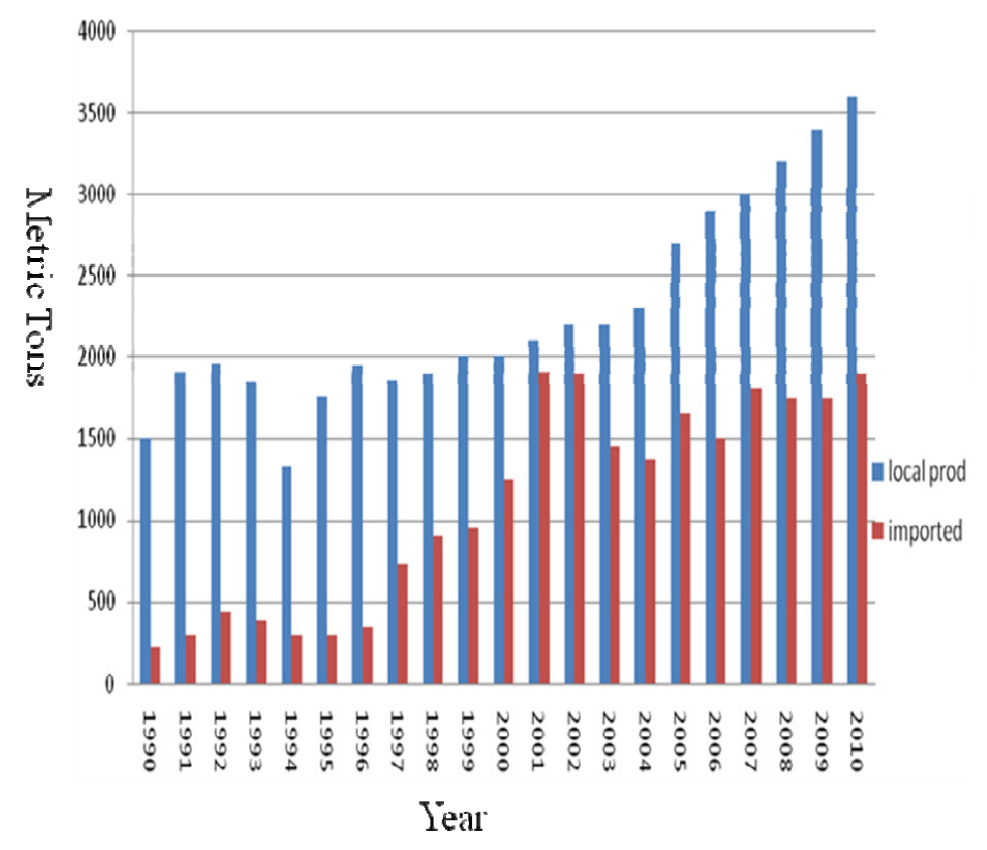

Figure 1. Nigeria milled rice production and importation for the past 21 years

Sources: USDA, 2011.

\section{Factors Influencing Weed Interference and Yield Losses in Rice}

\subsection{Critical Period of Weed Competition}

This period indicate the critical crop growth stage or the periods during which the field must be kept weed free (Akobundu, 1987). It is that shortest time span during the crop growth when weeding results in highest economic return. Generally, early one-third duration of the crop period should be maintained weed free. The critical period also differs with the cultivars used. For example, 20 days of weed free growth appears best in short-statured variety of rice. For an intermediate-statured variety, the weed free period should be extended to the first 30 days after planting. Generally, weed competition is less under flooded condition where rice is transplanted as compared to upland situations.

Johnson (1996) suggested that minimizing weed competition during the early stages of the crop before the formation of close leaf canopy is particularly important. He observed that this critical period in upland rice is 
approximately 15-40 DAS and weeds must be controlled within the period. Where a rice plant is exposed to prolonged weed competition during the critical period, it is not usually able to recover sufficiently to give good yield. Johnson (1996) therefore noted that hand weeding at 15 and 30 DAS increased grain yield by $60 \%$ over a single hand weeding at 30 DAS.

\subsection{Losses Caused by Weeds in Rice Production}

Grain yield losses due to weeds in lowland rice fields range from $20 \%$ to $60 \%$ in transplanted crops and from $30 \%$ to $80 \%$ in direct-seeded rice (Janiya, 2002). Rodenburg and Johnson (2009) however, reported rice yield losses due to uncontrolled weed growth in the range of $28-74 \%$ in transplanted lowland rice and $28-89 \%$ in direct-seeded lowland rice.

Generally, weeds are more efficient in utilizing the applied Nitrogen fertilizer than the rice plant. Mukhopadhyya (1974) observed that uncontrolled weeds in rice field removed $30-37 \mathrm{~kg} \mathrm{~N} \mathrm{ha}^{-1}$, while upland rice removed only $1.4-15.0 \mathrm{~kg} \mathrm{~N} \mathrm{ha}^{-1}$ but when weeds were controlled by herbicide, they removed only 4.6-10.8 $\mathrm{kg} \mathrm{N}$ ha. In weed-free plots, the rice crop used $80-89 \mathrm{~kg} \mathrm{~N} \mathrm{ha}^{-1}$ of applied fertilizer for good yield.

Conversely, Idem and Showemimo (2004) noted that competition of weeds with upland rice for moisture, nutrient and light resulted into a substantial yield reduction to the tune of $80-100 \%$, depending on the local weed flora, growth characteristics and environmental factors at the time of crop production. This assertion agreed with that of Zhang (2001) who reported that in China, 10 million tonnes of rice were lost annually due to weed competition and such quantity of rice was sufficient to feed at least 56 million people for one year. While in Sri-Lanka, a country considered self - sufficient in rice production, weeds remain the major biotic stress in rice production accounting for 30-40\% of the yield losses (Zhang, 2001). However in Nigeria, heavy weed infestation in direct seeded rice, upland or lowland, has been reported to cause as high as $44-100 \%$ yield loss (Akobundu, 1987). Studies in West Africa estimated that loss to weeds were 33-75\% in low land and $70-100 \%$ in upland rice (WARDA, 1984). In the same vein Posner et al. (1991) found that rice yield declined by $25 \mathrm{~kg} \mathrm{ha}^{-1}$ for each day the farmer delayed weed removal beyond 14 days after seeding.

\subsection{Indirect Losses Due to Weeds Infestation}

Weeds cause many other types of losses in rice fields that cannot be readily related to their presence. These losses are indirect in nature and include: (i) their serving as alternative host to pests and diseases (ii) increasing the time / cost of farm operation (iii) reducing the quality of harvested products (iv) limiting the size of the farm (v) affecting human health. It is widely recognized that weeds do not only compete with crops for nutrients, water and light, but may produce allelochemicals that may interfere with crop growth (Akobundu, 1987). In some villages in Nigeria, farmers are graded based on their ability to manage weed effectively on their farms.

\section{Weed Management Practices in Rice Production}

Weed management in rice production involves the ability to manipulate weeds so that they do not seriously interfere with the growth, development and yield of rice. It encompasses all aspects of weed control including prevention and the manipulation of rice growing environment and modification of crop growth habit inorder to interfere with the weeds ability within the environment (Akobundu, 1987). This author further observed that efficient weed management is a primary objective of all meaningful agricultural activities.

\subsection{Preventive Method}

Preventive weed control in rice refers to those activities that prevent the introduction of new weed species into a rice field as well as spreading and multiplication of an existing weed species including all sanitation measures such as:

\subsubsection{Use of Clean Seed in Rice Production}

Annual weeds like Oryza barthii and Echinochloa colona are known to mimic cultivated rice by synchronizing their growth cycles to that of the rice thereby producing seed at the same time with it. Thus; more often than not, the seeds of these weeds are harvested along with rice. Trainor and Bussan (2000) observed planting clean seed is key to preventing new weeds from invading a new field. Farmers should therefore maintain weed free rice fields and ensure proper cleaning of the seed intended for planting in the following season. This can be done by manual winnowing or hand picking with the use of mechanical cleaner. Rouging of rice fields can help in obtaining weed-free rice seed. Farmers should endeavour to acquire rice seed from the right source like the Agricultural Development Project or relevant Research Institutes.

\subsubsection{Preventing Weeds from Setting Seeds}

Pearson (2004) observed that one year weed seeding equals seven years weeding. Effort should therefore, be 
made to disallow weed from setting seeds, and this can be done by hand-slashing or mowing with machinery prior to flowering. Farmers should engage in post-harvest weed control to disallow weeds from setting seeds. This serves as investment that will pay off in reducing cost of weed control in the subsequent season. Akonbudu (1987) observed that preventing weed from setting seeds is another way of reducing weed infestation.

\subsubsection{Use of Clean Farm Tools}

Cultivation tools ranging from simple hoe, through animal-drawn tillers used in lowland rice to the most sophisticated farm machinery like plough or harrow must be cleaned immediately after use. This will prevent accidental transportation of weed propagules from one place to another.

Other practices that can be adopted by farmers in order to prevent weeds moving into a new place are keeping irrigation and drainage channels free from weeds, keeping nursery fields weed free, use of well rotten and decomposed organic manure and control of the movement of livestock.

\subsection{Cultural Method}

The basic principle of cultural weed control is to increase the competitive ability of rice to enable it suppress weed growth. A more vigorous rice crop competes effectively with weeds than the less vigorous.

\subsubsection{Good Land Preparation}

These preparations include ploughing, harrowing, puddling and leveling. A well prepared field allows the rice crop optimal early vigorous growth which gives it an edge over weeds. Nyarko and De Datta (1991) indicated that in order to destroy as many weeds as possible, the interval between ploughing and harrowing should be long enough to allow many weed seeds to germinate and be killed by the later operation which lead to $50 \%$ reduction in weed seed population.

The field must be well leveled particularly in the lowland ecology to allow even distribution of water on the field. A well leveled field without numerous depressions or elevations is essential for good weed control. Fields with many low and high spots result in water depths that are too deep for rice in low spots and too shallow for weed control in high spots (Eastin, 1981). Tillage during the dry season is a practical method of controlling perennial grasses such as Paspalum distichum, Cynodon dactylon, Oryza longistaminata and Imperata cylindrica. The harsh weather condition during this season desiccates their perennial structures.

\subsubsection{Planting Methods}

The major planting methods commonly adopted in Nigeria are drilling, broadcasting and transplanting. In a lowland ecology, transplanting of rice seedlings at the age of 20-30 days after sowing (DAS) immediately after the completion of land preparation should be adopted as it gives the rice head start against weeds. It is noted that transplanted rice reduces weed population since the crop has an additional advantage due to its age as the result of covering the ground early. Transplanting rice seedlings, gives the crop a 14 to 21 days growth advantage over the weeds, and allows continuous flooding at greater depths. During transplanting, weed seedlings are also trampled and incorporated into the soil.

In the upland ecology dibbling on the straight line at definite spacing should be adopted for effective weed management. When mechanical planter is to be used, sowing should be done 2-3 days after irrigation. At this stage weed seeds present in the soil start germinating, the sowing operation with seed drill removes some of the germinating weeds as the blade harrow is run to cover the seeds. During this process, all the surface soil to a depth of $2-3 \mathrm{~cm}$ is disturbed, thereby uprooting the germinating seeds. In addition, loosening of surface soil, dries up quickly and does not allow weed seeds to germinate until subsequent rain or irrigation. For this reason weed population is high when irrigation is given after sowing or rain is received after sowing. Therefore planting should be done on the flat as this result in higher plant population which gives the crop advantage over the weeds.

\subsubsection{Varietal Selection}

Short statured, erect leaved varieties permit light penetration compared to tall and leafy traditional varieties. Some of the crops grow quickly and produce early canopy resulting in shading and thus suppress weed growth. Improved rice cultivars resistant to diseases and insects are more competitive against weeds than the traditional rice. For instance, Kolo and Ismaila (2011) indicated that rice differ in the ways they suppress weeds and NERICA rice varieties suppressed weed better in upland ecologies than other rice varieties tested, and suggested the use of NERICA varieties in upland ecologies in order to enhance weed competiveness and yield. 


\subsubsection{Water Management}

Since time immemorial, water has been used to manage weeds in lowland ecology. Water management for weed control is an effective method of weed control strategy as most weed species in rice fields are only semi-aquatic and their growth can be retarded and ultimately controlled by standing water (Rainbolt \& Breck, 2006). Akonbudu (1987) reported that flooding is a cultural weed control method used in paddies, partly to meet the water requirements of paddy rice and partly to control weeds. However the use of flooding to control weeds has some limitations as it is not effective on well established aquatic weeds that cannot be submerged. Flooding is limited to where water is available and can be pounded and it requires a terrain that is level or can be leveled (Akobundu, 1987).

The flooding of rice field is the most effective cultural practice for weed control in lowland rice ecology and constant water height of $8-15 \mathrm{~cm}$ prevents the germination of most weed seeds and kills the majority of emerged weed seedlings (Thomas et al., 1983). In order to achieve effective water management, the field must be bonded as shown in Figure 2.

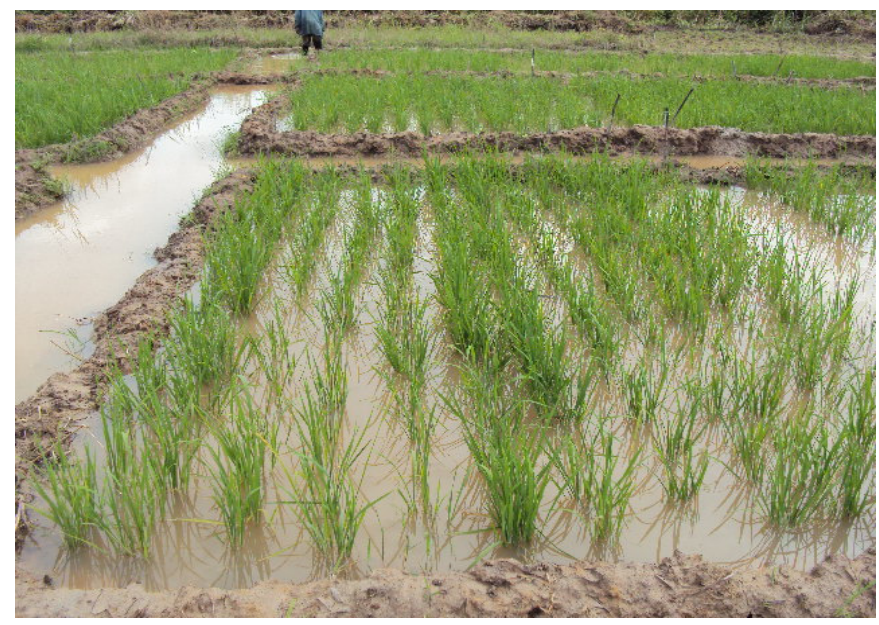

Figure 2. Continuous flood of rice fields to control weeds

\subsubsection{Crop Rotation}

Crop rotation involves alternating different crops in a systematic sequence in the same land. Weed species with growth requirements that are similar to the crop in which they are found tend to thrive. Rotation of low land rice fields with root crops like cassava and yam has been found to reduce the incidence of some annual weeds. The work of Gbanguba et al. (2011) indicated that planting of short duration cassava varieties after harvesting the low land rice tends to reduce the weed infestation. The residual moisture in the fadama ecology is enough to sustain the growth of the short duration cassava between December to April thereafter the same land will be used to grow rice again. Crop rotation helps to interrupt the life cycle of some weeds and thereby eliminate or reduce difficult weeds. Weeds like Cyperus rotundus can be controlled effectively by including lowland rice in crop rotation in place of upland rice. Other smothering crops in rotation like fodder grasses and majority of pulses control weeds effectively. In continuously transplanted rice fields under irrigated conditions, Scripus maritimus persists. When upland crops were rotated with rice, the population of this weed was reduced drastically even without the adoption of weed control measures (Gbanguba et al., 2011).

\subsubsection{Plant Population}

Spacing of rice plant is an important production factor. Density per unit area determines the amount of shade created to help the rice plant to compete with weeds for the growth factors. Nyarko and De Datta (1991) observed that light penetration into the rice canopy increases as the row spacing increases which stimulates weed growth and reduces rice yield. Higher plant population and narrow row spacings can put pressure on the availability of space for weeds growth (Table 2). On the other hand, too thick a stand should be avoided because it tends to increase lodging, prevents the full benefit of nitrogen application (Anon, 1986) and increases the chances of rat damage (Castin \& Moody, 1989).

Ismaila et al. (2012) confirmed that the closer spacing of $20 \mathrm{~cm}$ between and within rows reduced the weed 
biomass and increased the rice grain yield than the wider spacing of 30 to $50 \mathrm{~cm}$. Odero and Rainbolt (2011), observed that poor stand of rice encourages infestation by weeds such as Commelina spp and Ludwigia spp. These weeds can become established in areas of open water where the rice population is sparse. In a solid stand of rice, these weeds usually cannot compete for essential sunlight and do not become a problem.

Table 2. Effect of plant spacing on weed weight in lowland irrigated rice in West Africa

\begin{tabular}{ccc}
\hline Plant spacing & Weed weight $\left(\mathrm{g} \mathrm{m}^{-2}\right)$ & Grain yield $\left(\mathrm{t} \mathrm{ha}^{-1}\right)$ \\
\hline 14 & 40.6 & 4.2 \\
20 & 69.5 & 5.0 \\
30 & 82.3 & 4.4 \\
40 & 106.5 & 3.4 \\
\hline
\end{tabular}

Source: Johnson, 1996.

\subsubsection{Fertilization}

The common nutrients applied to the soil by rice farmers in Nigeria are Nitrogen $(\mathrm{N})$, phosphorus $(\mathrm{P})$ and potassium $(\mathrm{K})$. Nitrogen encourages rapid vegetative growth resulting in increased height, tiller number and leaf size, thus producing shade that help to suppress late-germinating weeds. Phosphorus on the other hand encourages root development and increases rice tillering. Vigorous root growth is advantageous in below-ground competition with weeds for moisture and nutrients. Weeds are more efficient in nutrients uptake than rice, therefore, it is important to keep the fields weed free before fertilization. Nyarko and De Datta (1991) observed that there is little or no response to $\mathrm{N}$ by rice in the shade, and $\mathrm{P}$ and $\mathrm{N}$ left on the soil surface will stimulate growth of shallow weed seeds. Therefore, care should be taken to apply fertilizers appropriately and efficiently.

Considering the slow release of $\mathrm{P}$ and $\mathrm{K}$ and their role in root development, it is advisable to apply them immediately after land preparation or at planting, while $\mathrm{N}$ which is highly mobile should be applied in two split doses at active tillering and panicle initiation stages. The use of this method is impeded by the late release of fertilizers to farmers by the government which had for quite sometime has been the only source for fertilizer distribution.

\subsubsection{Burning}

This is a common method under slash-and burn system of land preparation. This method kills weed seeds, seedlings and gets rid of unwanted vegetation and reduces the amount of weed seeds returned to the soil. Thorough burning can keep the rice field free of weeds for the first 2 - 3 weeks after planting (WAP) (Nyarko \& De Datta, 1991). This saves labour and cost and adds neutralizing ash to the soil. On the other hand, widespread and uncontrolled burning leave the soil bare, thereby increasing the possibility of soil erosion and loss of $\mathrm{N}$ and other soil nutrients. Controlled burning must be adopted in areas where other methods may prove ineffective or costly especially in the southern parts of Nigeria.

\subsubsection{Legume Break}

As weeds and living mulch plants (legume) compete for the same resources, they can be suppressed by the introduction of living mulches into the cropping systems. Teasdale and Daughtry (1993) observed that if a cover crop becomes established before the emergence of weeds, then the presence of green vegetation covering the soil creates a radiation environment that is unfavorable for weed germination, emergence, and growth which is a better environment for rice growth.

The authors also observed that several requirements for breaking dormancy and promoting germination of weed seeds in soils are reduced more by living mulches than by desiccated residue. Once established, living mulch also can use the light, water, and nutritional resources that would otherwise be available to weeds. Allelopathy is another mechanism by which living mulches may suppress weeds (Fujii, 1999). 


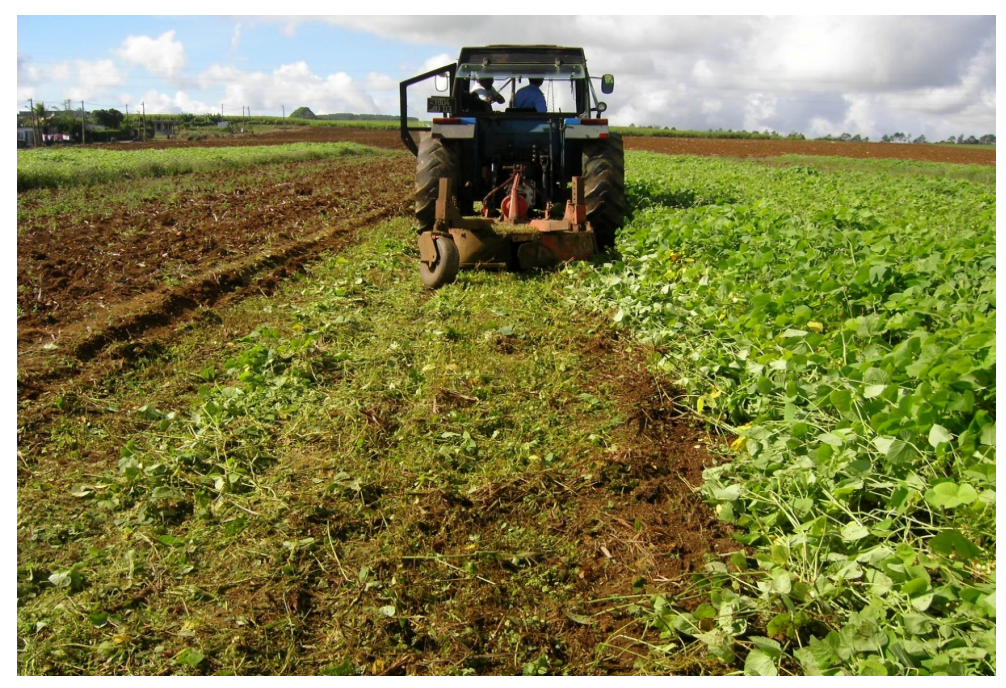

Figure 3. Incorporation of lablab used as legume break to control weeds

Generally, vigorous cover crops like Mucuna spp, Vigna unguiculata and Lablab purpureus are effective in smothering the growth of weeds (Teasdale et al., 2007). The lowland rice farmers should keep their field busy with legumes like lablab during the off-season to be incorporated into the soil in order to reduce weed infestation and also to improve soil fertility in the subsequent season (Figure 3). The limitation to the adoption of this method is that money and labour are required to maintain the legume and the farmers perceive no immediate benefits and are thus reluctant to adopt.

\subsubsection{Intercropping}

Intercropping involves growing a smother crop between rows of the main crop. It plays a vital role in weed management in upland rice in Nigeria. Usman et al. (2002) indicated that intercropping groundnut with rice in upland ecology greatly reduced the weed biomas. However, it is advised that the use of intercropping as a strategy for weed control should be approached carefully. Intercrops can greatly reduce the yields of the main crop if competition for water or nutrients occurs. Nevertheless, growing of cowpea in between the rows of upland rice reportedly resulted in an energy saving up to $315 \mathrm{MJ} / \mathrm{ha}$ compared to the recommended practice and specific energy requirement was $42.0 \mathrm{MJ} /$ ha than from hand weeding (Gogoi et al., 1997).

\section{Limitation to cultural weed control methods:}

$>$ Need good knowledge and understanding of various cultural practices that can reduce weed pressure

$>$ Continuous vigilance and monitoring for effective results and

$>$ Some of the methods are labour intensive

\subsection{Physical Methods}

\subsubsection{Hoe Weeding}

Despite major advantages derived from chemical weed control, hoe removal of weeds still remains the most practical method of weed control in many developing countries. Although back breaking and laborious, hoe weeding is quite effective if employed at the right time. The number of hoe weedings depends on crop and weed growths and the critical period of crop-weed competition.

Hoe hoeing is done in upland ecology where the entire surface soil is dug to shallow depths with hand hoes, and weeds are uprooted and removed. It also improves soil physical condition as 2-3 manual weeding at 25 and 45 DAS in direct seeded rice and at 15 and 30 days after transplanting in transplanted rice are reported as the best and most effective way of weed management.

\subsubsection{Hand Pulling}

This involves the physical removal of the weed from the field by hand. This method is commonly practiced in the low land rice ecology. Farmers should integrate this method with either chemical or cultural weed control methods like flooding. Those weeds that cannot be effectively controlled by herbicide or cultural means can be 
uprooted and discarded in such a way that they it have no chance to re-establish themselves.

\section{Limitations of hand weeding}

$>$ Is labor-intensive and time-consuming

$>$ Requires high drudgery and stress on labor (bending all the time to remove weeds)

$>$ Is difficult if the soil surface is not moist and loose

$>$ Costly

$>$ Often difficulty in identifying and removing certain grassy weeds at early stages (e.g. red rice, Echinochloa spp.).

$>$ Weeds may survive if pulled and dropped into standing water (Leela \& Raju, 2011).

\subsection{Integrated Weed Management (IWM)}

This is neither weed control method nor a system; rather it is a philosophy whose goal is to use all available knowledge in weed science to manage weeds in such a way that they do not cause economic loss to humans (Akobundu, 1987). This implies the combination of two or more weed management methods at low cost to obtain the level of weed suppression superior to that ordinarily obtained when one weed management system is used. Integrated weed and crop management is not a new concept so, in theory, improved techniques need not be alien to farmers. However, farmers tend to be conservative and reluctant to change traditional practices, especially if they perceive risks.

Some of the reasons that make IWM desirable were given by Akobundu (1987) as: (a) inability of any single weed control method to completely solve the weed problem of any given crop at all times without adverse effect; (b) tendency of weeds to adapt to a given cropping system and thus escape control; (c) ability of weeds to develop resistance against herbicide; (d) tendency of certain cropping systems to favour the dominance of specific weeds; (e) long-season crops such as cassava and yams with extended critical periods of sensitivity to weed competition; and (f) seasonal fluctuation of labour availability.

Advantages of integrated weed management in rice production include:

$>$ It shifts the crop-weed competition in favour of the crop

$>$ Prevents weed shift towards perennial nature

$>$ Prevents resistance in weeds to herbicides

$>$ No danger of herbicide residue in soil or plant

$>$ No environmental pollution

$>$ Gives higher net return

$>$ Suitable for high cropping intensity (Leela \& Raju, 2011).

\subsection{Chemical Weed Control Method}

The chemicals used to control weed is called herbicide and its use have improved weed management and contributed substantially to yield increases in rice production (Hill \& Hawkins, 1996). The use of herbicides is one of the main factors enabling intensification of rice production in the past decade. Herbicides are one of the labour saving technologies to be adopted as the labour cost rises (Jata \& Pawan, 2006). The authors observed that herbicides replace hand weeding and enable direct seeding rather than transplanting, which is less labour demanding.

\section{Advantages of chemical weed control method are:}

$>$ Herbicides are useful in areas where incessant rainfall may hinder the physical weeding.

$>$ Herbicide usage reduces the competition for labour during early stages of crop growth.

$>$ They control germinating weeds and thereby make the crop weed free and more competitive during early stages.

$>$ They are useful in controlling weeds which mimic crop plants.

$>$ Herbicides do not dictate strict row spacing.

$>$ They have long lasting effect on control of broad leaved weeds and perennial weeds.

$>$ Convenient to use on thorny /spiny weeds. 
$>\quad$ They are more efficient in controlling weeds on erodable soils where tillage may accelerate soil and water erosion.

$>\quad$ They kill the weeds in situ without dissemination of vegetative propagules.

$>$ Herbicide sprays easily reach the weeds growing in obstructed situation, under fruit trees and on undulating areas.

$>$ It provides greater possibility of mechanization.

$>\quad$ It makes harvesting easy.

$>\quad$ It leads to increased water use efficiency in dry land agriculture and less crop failures due to drought (Leela \& Raju, 2011).

\section{Conclusion}

In this review, the various causes of weeds destructive effects in rice production in Nigeria have been outlined. Affordable and easy to use technologies by the resource poor rice farmers to surmount weeds negative influence on rice production such as good land preparation, effective and efficient water management, integrated weed management strategies and chemical weed management options have been given.

The destructive and reductive effects of weeds ranging from 70-100\% in rice production have also been outlined. Rice farmers in Nigeria have the opportunity of availing themselves to the update information on effective weed management for increased rice production presented in this paper.

The paper also has information for government policy makers for adaptations in order to attain the lofty ideals in the present Agricultural transformation Agendato gauge the current huge import bills on rice. Finally, the review has strived to serve as compendium of information to researchers, extension agents, students and other professionals in the Agricultural sector of the Nigeria economy.

\section{References}

Akobundu, I. O. (1987). Weed science in the tropics. Principle and practices. Wiley interscience. Chischester. 33-35.

Anon. (1986). Mechanized rice production project at Rambia Mulanut and Kandol. Interim report for Malaut volume 2 Appendices Agriculture Development Corporation. Republic of Korea and Waston Hawksby Asia Negras Bnmei Darussalam.

Anon. (1996). Imperata Management for Smallholders: an extensionist's guide to rational Imperata management for smallholders. Indonesian Rubber Research Institute, Indonesia, and Natural Resources Institute, United Kingdom, p.56

Castin, E. M., \& Moody, K. (1989). Effect of different seedling rates, moisture regimes, and weed control treatments on weed growth and yield of wet-seeded rice. In: Proceedings of the $12^{\text {th }}$ Asia-Pacific Weed Science Society Conference, Seoul Korea, pp. 337-343.

Defoer, T., Wopereis, M. C. S., Jones, M. P., Lancon, F., Erenstein, O., \& Guei, R. G. (2006). Rice based production systems for food security and poverty alleviation in Sub-Saharan Africa. pp. 1-6. Retrieved from ftp://ftp.fao.org/docrep/fao/008/y5682e/y5682e02.pdf

Eastin, E. F. (1981). Weed management system for U.S. rice In: hand book of pest management in Agriculture, volume 3. CRC pess Boca Roton, Frorida, USA, pp. 539-547.

Fujii, Y. (1999). Allelopathy of hairy vetch and Macuna; their application for sustainable agriculture. pp. 289-300. In C. H. Chou, et al. Biodiversity and Allelopathy from Organisms to Ecosystems in the Pacific. Academia Sinica, Taipei.

Gogoi, S., P. H., Gogoi, A., Mazumder, \& Saikia, T. P. (1997). Integrated method of weed control in a seed crop of okra (Abelmouschus esculentus L. Moench.). Annal Agricultural Research, 18(4), 432-436.

Gbanguba, A. U., Ismaila, U., Kolo, M. G. M., \& Umar, A. (2011) Effect of cassava/legumes intercrop before rice on weed dynamics and rice grain yield at Badeggi. African journal of plant science, 5(4), 264-267.

Hill, J. F., \& Hawkins, L. S. (1996). Herbicides, in United States rice production: Lessons for Asia. In R. Naylor, (ed.). Herbicide in Asia rice: Transitions in weed management. Inst. For Int. stud. Stanford univ. palo Alto, CA and IRRI, (pp. 37-52). Manila, Philippines.

Holm, L. G. (1971). The role of weeds in human affairs. Weed science society of America, 19(5), 485-490. 
Idem , N. U. M., \& Showemimo, F. A. (2004). Cereals Crops of Nigeria, pp. 16-34.

Imolehin, E. D., \& Wada, A. C. (2000). Meeting the rice production and consumption demands of Nigeria with Imporved Technologies. In production and Research programme. Upland rice breeding Task Force Workshop. pp. 33 -34.

Ismaila, U., Kolo, M. G. M., \& Gbanguba, A. U. (2011). Effect of varieties and weeding regimes on weed and performance of two aerobic rice varieties. South Asia journal of experimental biology, 1(3), 121-130.

Ismaila, U., Kolo, M. G. M., \& Ndayako, U. (2012). Effect of spacing on weed control, growth and grain yield of upland rice at Badeggi, Nigeria. (in press: Nigeria journal of Agriculture).

Jata, S., Nanda, \& Pawan, K. (2006). Rice. Kalyani Ludhiana -New Delhi-Noida (U.P.). pp. 244-258.

Johnson, D. E., Riches, C. R., Kayeke, J., Sarra, S., \& Tuor, F. A. (1999). Wild rice in sub-Saharan Africa: its incidence and scope for improved management. Report of the global workshop on red rice control, 30 87-93.

Johnson, D. E. (1996). Weed management in small holder rice production in the tropics. In: Radeliffes, E.B., and Hutchison, W. D. (Eds). University of Minnesota, St. Paul, M. N., Retrieved from http://ipm World.umm.edu/chapter/johnson. htm

John, R., \& Leeper. (2010). Improving yield by controlling weeds. In rice today. Back to the basics, p. 12.

Janiya, J. D. (2002). Weed management in major crops in the Philippines. Los Baños, Laguna, Philippines: In Weed Science Society of the Philippines. Yield losses, major weed species, and suggested management systems in selected major crops: rice, pp. 17-37.

Kehinde, J. K. (2002). Influence of seed rate and weed management control and performance of upland rice. Nigeria Journal of Weed Science, 15, 1-6.

Kolo, M. G. M., \& Umaru I. (2011) Weed competitiveness and yield of inter- and intra-specific upland rice (Oryza sativa L.) under different weed control practices at Badeggi, Nigeria. in press: African journal of Agricultural Research, 7(11), 1687-1693. $\quad$ Retrieved from http://www.angrau.net/StudyMaterial/Agronomy/AGRO202.pdf

MacRobert, A. L., Jones, J., \& Kosina, P. (2007). Weed management in maize-based cropping systems in cereal knowledge bank. Retrieved from http://.knowledgebank.irri.org/ckb/agronomy-maize/weed-management-in-maize

Leela Rani, P., \& Raju, M. S. (2011). Lecture note on weed management. Department of agronomy. College of Agricure, Acharya N. G. Ranga Agricultural university Rajenranger, Hyderabad. pp. 56-90.

Mukhopadhyya, S. K. (1974). Increasing fertilizer efficiency through weed control. Upland rice research, proceedings of the 1982 Bouake, Ivory Coast Upland rice workshop. pp. 267-292.

Nyarko-Ampong, K., \& De Datta, S. K. (1991). A Handbook for Weed Control in Rice. International Rice Research Institute, P O Box 933, 1099 Manila, Phillipines.

Odero, D. C., \& Rainbolt, C. (2011). Weed management in rice. Agronomy Department, Florida Cooperative Extension Service, Institute of Food and Agricultural Sciences, University of Florida.

Pandey, L. J., Bouman, B. A. M., \& Hardy, B. (1999). Characterizing and understanding rainfed environments. Proceedings of the international Workshop on characterizing and understanding rainfed environments, Bal, Indonesia. Los Banos, Philippines, IRRI. pp. 97-110.

Posner, J. L., Kamuanga, M., \& Lo, M. (1991). Lowland cropping systems in the lower casamance of Senegal: MSU international development papers. Department of Agricultural Economics, Michigal State University (MSU), East Lansing, Michigan USA.

Pearson, D. (2004). One year's seed is seven weed. Retrieved from http://torontogardens.blogspot.com/2009/04/one-years-seeds-seven-years-weeds.html

Pandey Sharan. (2009). Effect of weed control on rice cultivars under the system of rice intensification (SRI). thesis submitted to the tribhuvan university institute of agriculture and animal science rampur, chitwan, nepal in partial fulfillment of the requirements for the degree of master of science in agriculture (agronomy). Retrieved from http://sri.ciifad.cornell.edu/countries/nepal/Nepal_SPandey_MSc_thesisIAAS09.pdf

Rice Today. (2010). International Rice Research Institute. 
Rodenburg, J., Diagne, A., Oikeh, S., Futakuchi, K., Kormawa, P. M., Semon, I., Akintoya, B., Cisse, B., Sie, M., Nerteh, L., Nwilene, F., Diatta, S., Sere, Y., Ndjiondjop, M. N., \& Keya, S. O. (2006). Achievements and impact of NERICA on sustainable rice production in sub - Saharan Africa. International rice commission newlatter, 55, 45-58.

Rodenburg, J., \& Johnson, D. E. (2009). Weed management in rice-based cropping systems in Africa. Advances in Agronomy, 103, 149-218. http://dx.doi.org/10.1016/S0065-2113(09)03004-1

Rainbolt, Curtis, R., \& Barry, J., (2006). Weed Management in Rice. Agronomy Department, Florida Cooperative Extension Service, Institute of Food and Agricultural Sciences, University of Florida.

Teasdale, J. R., Coffman, C. B., \& Mangum, R. W. (2007). Potential long-term benefits of no-tillage and organic cropping systems for grain production and soil improvement. Agronomy Journal, 99, 1297-1305. http://dx.doi.org/10.2134/agronj2006.0362

Teasdale, J. R., \& Daughtry, C. S. T. (1993). Weed suppression by live and desiccated hairy vetch. Weed science, 41, 207-212.

Thomas, J. M., Stephen, C. W., \& Floyd, M. A. (1983). Weed science: Principles practices. pp. 308-409.

Trainor, M., \& Bussan, A. J. (2000). Integrated Weed Management; Preventing Weed Invasion. Prairie Star April issue. Retrieved from http://scarab.msu.montana.edu/CropWeedSearch/Docs/IntegratedWeedManagement.htm

Usman, A., Adagba, M. A., Kehinde, J. K., Ukwungu, M. N., \& Ogunshola. T. O. (2002). The effect of intercropping groundnut with rice on weed and fertilizer management in upland rice. Proceeding of the $2^{\text {nd }}$ Biennial regional rice research review meeting at WARDA headquarter, M'be, Cote d'lvoire.

Ukwungwu, M. N., \& Abo, M. E. (2004). Nigeria rice: In the science and technology vista, the Nigeria rice memorabilia, p. 49.

USDA (United State department of agriculture). (2011). Nigeria rice production by year. Retrieved from $\mathrm{http}: / /$ www.indexmundi.com/agriculture/?country=ng\&commodity=milled-rice\&graph=imports

WARDA (West Africa Rice Development Association) (1984). Upland rice in West Africa. (pp. 21-43). An overview of upland rice research. Proceedings of the 1982 Bouake, Ivory Coast upland rice workshop. IRRI Los Baunos Philippines.

Zhang Ze pu (2001). Weed management in rice in China. Summary presented at FAO workshop on Echinochloa spp. Control, Beijing, China, 27 May 2000. 